\title{
Antioxidant potential and LC/MS metabolic profile of anticancer fractions from Echium angustifolium Mill. aerial parts
}

\author{
Hanan M. El-Tantawy, Ahmed R. Hassan* (D), Hala E. Taha \\ Medicinal and Aromatic Plants Department, Desert Research Center, Cairo, Egypt.
}

\begin{tabular}{l}
\hline ARTICLE INFO \\
\hline Received on: 05/07/2021 \\
Accepted on: 19/09/2021 \\
Available Online: 05/12/2021 \\
\hline Key words: \\
Echium angustifolium, \\
anticancer activity, \\
antioxidant activity, phenolic \\
acid derivatives, lignans.
\end{tabular}

\section{INTRODUCTION}

Echium angustifolium Mill., a member of the Boraginaceae family, is a perennial plant growing in the northwestern coastal region of Egypt and is utilized for various uses such as grazing, medical, and fuel purposes (Bidak et al., 2015). The leaves of E. angustifolium were used traditionally in the Arab region for hepatitis, jaundice, kidney conditions (especially stones), and skin problems (Ghazanfar, 1994), whereas the previous biological studies reported the antitumor activity for the plant's lignans (El-Rokh et al., 2018b), the insecticidal activity against Aphis craccivora for the volatile oil of the plant (El-Rokh et al., 2018a), the analgesic and antioxidant activity (Al-Rimawia et al., 2020; Eruygur et al., 2012), the wound healing activity

\footnotetext{
*Corresponding Author

Ahmed Ramadan Ahmed Hassan, Medicinal and Aromatic Plants Department, Desert Research Center, Cairo, Egypt.

E-mail:ahmedhasan_81@yahoo.com
}

(Eruygur et al., 2016), and its use in treating ciguatoxin toxicity and inflammation from snake venom (Sadawe et al., 2020).

Concerning the phytochemical reviews on the plant, it was found that pyrrolizidine alkaloids are common in the Echium genus (Kitessa et al., 2011), and echimidine was identified from E. angustifolium (Sarg et al., 1992). The total fat content was determined in the seeds, and the unsaturated fatty acids (linoleic, $\alpha$-linoleic, $\gamma$-linolenic, and stearidonic acids) were identified as the predominant components (Özcan, 2008). Additionally, analysis of the butanol fraction of the whole plant (fractionated from the methanolic extract) resulted in the identification of five lignans, namely echiumins A-D and trigonotin A, where the plant was collected from Abo-Mandor at the Rosetta branch of the River Nile, Egypt (El-Rokh et al., 2018b). Moreover, six naphthoquinones were identified from the roots' extract (Eruygur, 2018).

Since then, E. angustifolium has been considered an edible plant for animals, and the plant extracts were not examined previously for their in vitro anticancer activities except some pure isolated lignans against the HepG2 and MCF7 cancer cell lines (ElRokh et al., 2018b). Additionally, some other plant constituents 
might contribute to this activity. Accordingly, it was of interest in our study to further assess the total alcoholic extract and the fractionated extracts of this promising wild plant collected from another location in the Northwestern coastal desert of Egypt for its in vitro anticancer activity against liver and colon cancer cell lines and to characterize other chemical constituents that might induce this effect using LC-ESI-MS/MS, as well as evaluate the possible antioxidant potential for the potent fractions as a mechanism of action in relation to their chemical constituents.

\section{MATERIALS AND METHODS}

\section{Plant material}

The Echium angustifolium Mill. aerial parts were collected in April 2017 from the Northwestern coast of Egypt (Agiba region, Mersa Matruh Governorate). The plant material was authenticated by Professor Dr. Azza El-Hadidy, Professor of Plant Taxonomy at Cairo University, Egypt. A voucher sample (Ea-2017-A) was kept at the Herbarium of the Faculty of Science, Cairo University, Egypt.

\section{Extraction and fractionation of the $E$. angustifolium aerial parts}

The aerial parts of E. angustifolium were air-dried and then powdered. The powder $(2.0 \mathrm{~kg})$ was extracted with $80 \%$ ethanol $(80 \% \mathrm{EtOH})$ by maceration at room temperature $(3 \times$ 61 , each 48 hours). The combined extracts were concentrated under reduced pressure at $45^{\circ} \mathrm{C}$ till dryness to give $146 \mathrm{~g}$ of dried extract. The total extract was subjected to a biological screening (in vitro anticancer assay), followed by bioguided fractionation in order to isolate the active fractions by suspending them in $70 \%$ aqueous $\mathrm{MeOH}(600 \mathrm{ml})$ in a separating funnel using liquidliquid partition fractionation with $n$-hexane, yielding the fatted $n$-hexane fraction (Ea-F, $33.8 \mathrm{~g}$ ) and the defatted fraction (EaDf, $105 \mathrm{~g}$ ). The EaDf was subjected to in vitro cytotoxic assay, and the results indicated that the fraction has a significant activity. Hence, it was further subjected to fractionation on polyamide $6 \mathrm{~S}$ column chromatography using a gradient elution of $\mathrm{H}_{2} \mathrm{O}-\mathrm{EtOH}$ (100:0-0:100). All the obtained fractions (500 $\mathrm{ml}$ per fraction) were subjected to analytical normal phase TLC plates (silica gel 60 GF254 Normal phase-thin layer chromatography (NP-TLC); purchased from Merck, Darmstadt, Germany). These plates were seen under UV (254 and $365 \mathrm{~nm}$ ) and immersed in 5\% sulfuric acid in methanol followed by heating at $105^{\circ} \mathrm{C}$ for 3 minutes. The effluents characterized by similar TLC chromatographic patterns were combined and dried to give two promising subfractions (EaDfD, $0.94 \mathrm{~g}$, and Ea-DfE, $0.46 \mathrm{~g}$ ), followed by activity evaluation of these resultant fractions using in vitro cytotoxic and antioxidant assays. Finally, these two fractions were subjected to Liquid chromatography-electrospray ionization-mass spectrometry (LCESI-MS)/MS to identify their chemical constituents.

\section{LC-ESI-MS/MS profiling of the two subfractions (Ea-DfD and Ea-DfE)}

LC-ESI-MS/MS analysis was assessed for the two subfractions (Ea-DfD and Ea-DfE) from the total extract of the $E$. angustifolium aerial parts via ACQUITY UPLC ${ }^{\text {TM }}$. This apparatus is equipped with a BEH-C18 column of dimensions $2.1 \times 50 \mathrm{~mm}$ and a $1.7 \mu \mathrm{m}$ particle size (Waters, Milford, CT). The mobile phase is composed of acidified $\mathrm{H}_{2} \mathrm{O}$ with $0.1 \%$ formic acid (A) and acetonitrile containing $0.1 \%$ formic acid (B). The gradient system with a flow rate $0.2 \mathrm{ml} /$ minute was as follows: $0-2$ minutes $(\mathrm{A}: \mathrm{B}$ $90: 10, \mathrm{v} / \mathrm{v}), 2-5$ minutes (70:30), 5-15 minutes (30:70), 15-22 minutes (10:90), 22-25 minutes (10:90), 26-29 minutes (0:100), and 29-32 minutes $(90: 10)$. The detector (ESI) in both modes was used within the $m / z$ range of 100-1,000 (Al-Madhagy et al., 2019). Parameters were as follows: capillary voltage $3 \mathrm{kV}$, cone voltage $30 \mathrm{eV}$, dissolution gas flow $600 \mathrm{l} /$ hour, cone gas flow $50 \mathrm{l} /$ hour, and source and dissolution temperatures $150^{\circ} \mathrm{C}$ and $400^{\circ} \mathrm{C}$, respectively. MassLynx 4.1 software was used for mass spectra processing, and the peaks of the compounds were annotated by comparing their molecular and fragmentation ions to the literature.

\section{In Vitro cytotoxic assay}

The human colorectal [Human Colorectal Carcinoma cell line (HCT116)] and hepatocellular [Human hepatocellular carcinoma G2 (HEPG2)] carcinoma cell lines were acquired from the American Type Culture Collection and kept at $-180^{\circ} \mathrm{C}$ in liquid nitrogen and then subcultured in the National Cancer Institute, Egypt. These cancer cells were suspended in a RPMI 1640 medium (Sigma-Aldrich, USA) in 1\% L-glutamine (Lonza, Belgium), 10\% fetal bovine serum (Sigma-Aldrich, USA), and 1\% from the mixture of antibiotic $(10,000 \mathrm{U} / \mathrm{ml}$ streptomycin sulfate and 10,000 U/ml K-penicillin) and antimycotic $(25 \mu \mathrm{g} / \mathrm{ml}$ amphotericin B), which was purchased from Lonza, Belgium. The total extract of the aerial parts of $E$. angustifolium (Ea), the EaDf, and the two subfractions (Ea-DfD and Ea-DfE) were evaluated for cytotoxicity potential according to the method previously described by Skehan et al. (1990). Cells $\left(10^{4}\right.$ cells/ well) were put in a microplate (96 wells) for 24 hours. Triplicates of concentrations of each sample $(50,25,12.5$, and $5 \mu \mathrm{g} / \mathrm{ml})$ beside the negative control were added to the wells and incubated at $37^{\circ} \mathrm{C}$ in $5 \% \mathrm{CO}_{2}$ for 48 hours. Then, cells were stained with sulforhodamine B stain. Acetic acid was used to remove the excess stain; the fixed stain was dissolved in Tris-Ethylenediamine tetraacetic acid (EDTA) buffer. An Enzyme-linked immunosorbent assay (ELISA) reader was used to detect the color intensity. The viable cells showed the relation between surviving fraction and extract concentration. The $\mathrm{IC}_{50}$ value of the tested extracts was deduced and expressed as $\mathrm{IC}_{50}$ $\pm \mathrm{SD}$ (triplicate).

\section{Antioxidant activity}

The antioxidant activity of the two subfractions (Ea-DfD and Ea-DfE) was assessed using four different in vitro methods: 2,2'-diphenyl-1-picryl-hydrazyl hydrate (DPPH), 2,2'-azino-bis(3ethylbenzothiazoline-6-sulphonate) (ABTS), ferric-reducing ability power (FRAP), and oxygen radical absorbance capacity (ORAC). All the results were recorded using a microplate reader FLUOstar Omega (BMG LABTECH, Germany).

\section{DPPH free radical assay}

An initial screening step was carried out to identify the range of $\mathrm{IC}_{50}$. Solutions of 1,000 and $100 \mu \mathrm{g} / \mathrm{ml}$ in alcohol from both Ea-DfD and Ea-DfE samples were prepared and tested. Then, the concentrations of $60,50,40,30$, and $20 \mu \mathrm{g} / \mathrm{ml}$ were prepared. A Trolox standard was prepared as a stock solution of $100 \mu \mathrm{M}$ in methanol, and then seven concentrations were prepared from it: $50,40,30,20,15,10$, and $5 \mu \mathrm{M}$. In a 96-well plate, $100 \mu \mathrm{l}$ of 
a freshly prepared $0.1 \%$ DPPH reagent in methanol was mixed with $100 \mu \mathrm{l}$ of the tested extracts $(n=3)$. Then, the reaction was incubated for 30 minutes at room temperature in the dark (Boly et al., 2016), and the reduction in DPPH color intensity was detected at $540 \mathrm{~nm}$. Data and $\mathrm{IC}_{50}$ value calculation was analyzed by Microsoft Excel ${ }^{\circledR}$ and GraphPad Prism $5 \AA$ and represented as means \pm SD according to the following equation:

$\%$ inhibition $=[(\mathrm{Ac}-\mathrm{As}) / \mathrm{Ac}] \times 100$.

ABTS assay

$1 \mathrm{mM}$ of Trolox in methanol was prepared as a stock solution, and then five serial dilutions $(600,500,400,300,200$, 100 , and $50 \mu \mathrm{M}$ ) were prepared, whereas $0.1 \mathrm{mg} / \mathrm{ml}$ from both EaDfD and Ea-DfE samples in alcohol was prepared. The assay was carried out in microplates with minor modifications to the method of Arnao et al. (2001); briefly, $192 \mathrm{mg}$ of ABTS was dissolved in a $50 \mathrm{ml}$ volumetric flask with distilled water. After that, $1 \mathrm{ml}$ of this solution was added to $17 \mu \mathrm{l}$ from $140 \mathrm{mM}$ of potassium persulfate and left for 24 hours in the dark. $1 \mathrm{ml}$ of the reaction mixture was diluted with methanol to the volume of $50 \mathrm{ml}$ to obtain the final ABTS reagent used in the assay. $190 \mu \mathrm{l}$ of this freshly prepared ABTS reagent was added to $10 \mu 1$ of each sample $(n=4)$ and left in the dark for 120 minutes. Finally, the decrease in ABTS color intensity was analyzed at $734 \mathrm{~nm}$, and means \pm SD were calculated according to the equation described above. The results are expressed as $\mu \mathrm{M} \mathrm{TE} / \mathrm{mg}$ sample using the linear regression equation extracted from the linear dose-inhibition calibration curve of Trolox.

\section{FRAP assay}

$5 \mathrm{mM}$ in methanol of Trolox was prepared as a stock solution, and 10 serial dilutions $(4,000,3,000,2,000,1,000,800$, $600,400,200,100$, and $50 \mu \mathrm{M}$ ) were prepared. A concentration of $0.1 \mathrm{mg} / \mathrm{ml}$ from the two samples was prepared in $70 \%$ ethanol. The FRAP assay was evaluated in microplates by Benzi and Strain (1996), with minor changes; briefly, a fresh 2,4,6-tripyridyl-striazine (TPTZ) reagent was prepared from $10 \mathrm{mM}$ TPTZ in $\mathrm{HCl}$ (40 mM), $300 \mathrm{mM}$ acetate buffer of $\mathrm{pH} 3.6$, and $20 \mathrm{mM} \mathrm{FeCl}_{3}$ in 1:10:1 v/v/v, respectively. In a 96-well plate, $190 \mu 1$ from TPTZ was added to $10 \mu \mathrm{l}$ of the sample $(n=3)$, incubated at the same conditions, and measured at $\lambda=593 \mathrm{~nm}$. The ferric-reducing ability of the samples is expressed as $\mu \mathrm{M} \mathrm{TE} / \mathrm{mg}$ sample by the linear regression equation extracted from the linear dose-response calibration curve of Trolox.

\section{ORAC assay}

$1 \mathrm{mM}$ of Trolox in methanol was prepared as a stock solution, and nine serial dilutions (400, 300, 200, 150, 100, 75, 50, 25 , and $12.5 \mu \mathrm{M})$ were prepared. The tested samples $(20 \mu \mathrm{g} / \mathrm{ml})$ were prepared in methanol. The ORAC assay was evaluated based on Liang et al. (2014), with minor modifications; briefly, $12.5 \mu 1$ of the tested samples was mixed with $75 \mu$ l fluoresceine $(10 \mathrm{nM})$ and incubated for 30 minutes at $37^{\circ} \mathrm{C}$. Fluorescence measurement (485 EX, 520 EM) was carried out for three cycles (cycle time, 90 seconds) for background measurement. Then, $12.5 \mu 1$ from 240 $\mathrm{mM}$ of 2,2-azobis(2-amidinopropane) was prepared and added immediately to each well, and fluorescence measurement was continued for 2.5 hours (100 cycles, each 90 seconds). Data are represented as means $(n=3) \pm \mathrm{SD}$, and the results are presented as $\mu \mathrm{M} \mathrm{TE} / \mathrm{mg}$ sample using the linear regression equation extracted from the linear dose-inhibition calibration curve of Trolox.

\section{RESULTS AND DISCUSSION}

The in vitro anticancer activity for the total extract $(80 \% \mathrm{EtOH})$ of the E. angustifolium aerial parts was firstly screened, followed by bioguided fractionation, whereas the total extract was subjected to different chromatographic fractionations until it afforded two promising subfractions (Ea-DfD and EaDfE) accompanied by evaluation of their in vitro cytotoxic and antioxidant activities. Finally, these two fractions were subjected to LC-ESI-MS to identify the chemical profile.

\section{In vitro anticancer activity}

To assess the anticancer effect of the E. angustifolium plant, the total alcoholic extract was screened against liver and colon cancer cell lines (HEPG2 and HCT116, respectively), and it possessed a potential anticancer effect. The extract inhibited the growth of both tested cell lines HEPG2 and HCT116 with $\mathrm{IC}_{50}$ of $22 \pm 0.6$ and $15 \pm 1.1 \mu \mathrm{g} / \mathrm{ml}$, respectively, as listed in Table 1. These results suggested bioguided fractionation by hexane to yield fatted and defatted fractions that were also screened against the same previous cell lines. The EaDf showed good growth inhibition for both liver and colon cancer cells with $\mathrm{IC}_{50} 20 \pm 0.6$ and $19.7 \pm 1.1 \mu \mathrm{g} / \mathrm{ml}$, respectively. Consequently, fractionation of the defatted part on the polyamide column was carried out to yield several fractions that were also biologically screened against the same previous cell lines. It was found that only two fractions from the polyamide column (Ea-DfD and Ea-DfE) possessed potent anticancer activity. Ea-DfD induced $\mathrm{IC}_{50} 10 \pm 0.2$ and $4 \pm 0.8 \mu \mathrm{g} /$ $\mathrm{ml}$, while Ea-DfE induced $\mathrm{IC}_{50} 4 \pm 0.5$ and $11 \pm 0.7 \mu \mathrm{g} / \mathrm{ml}$ against HEPG2 and HCT116, respectively (Table 1). These values of $\mathrm{IC}_{50}$ were comparable to those induced by doxorubicin $(4.57 \pm 0.5$ and $3.73 \pm 0.6 \mu \mathrm{g} / \mathrm{ml}$ against HEPG2 and HCT116, respectively). The antitumor activity of two previously isolated lignans from $E$. angustifolium against breast and liver cell cancer lines (MCF7 and HepG2) was proved, and they displayed promising in vitro antitumor activity lignans (El-Rokh et al., 2018b). This previous report was found to be consistent with the above results, as different lignans were detected in the tested fraction (Ea-DfD) by the LC/ MS technique. Additionally, the presence of different phenolic acids' derivatives with hydroxyl group substitution which were identified in both tested fractions (Ea-DfD and Ea-DfE) by LC/ MS was known to induce anticancer effect via their antioxidant role (Godlewska-Zyłkiewicz et al., 2020; Teixeira et al., 2013). Therefore, it can be assumed that the possessed anticancer effect of Ea-DfD and Ea-DfE on liver and colon cell lines is due to their enrichment with lignans and hydroxyl phenolic acids' derivatives.

\section{Antioxidant activity}

Oxidative stress is a well-known cause of cancer, and antioxidants' role in cancer inhibition and treatment is clear. Additionally, most plants are good sources of antioxidants, and the free radical scavenging activity of E. angustifolium polar fraction was previously evidenced by the DPPH method (Bahmani et al., 2017; Al-Rimawia et al., 2020). Considering that Ea-DfD and EaDfE possessed good anticancer activities, it was of value to study also their antioxidant potential as a possible mechanism of action. To assess antioxidant activity, four different in vitro methods 
(DPPH, ABTS, FRAP, and ORAC) were applied for each of EaDfD and Ea-DfE active fractions and repeated thrice to verify the reproducibility of these tests. According to the mechanism of reaction, all of them are categorized as electron transfer methods except ORAC that is a hydrogen-transfer method (Dontha, 2016).

Herein, all the applied methods showed the strong antioxidant activity of both fractions. Regarding the DPPH assay, it was found that fraction Ea-DfE highly inhibited the DPPH free radical with $\mathrm{IC}_{50} 25.06 \mu \mathrm{g} / \mathrm{ml}$ that is more reactive than Ea-DfD with $\mathrm{IC}_{50} 42.61 \mu \mathrm{g} / \mathrm{ml}$ and very close to Trolox (reference drug) that exhibited $\mathrm{IC}_{50}$ of $24.42 \mu \mathrm{g} / \mathrm{ml}$ as represented in Table 2 and shown in Figure 1. Additionally, the ABTS, FRAP, and ORAC results were also similar to those found in the DPPH and confirmed the antioxidant potential of the tested fractions as both Ea-DfD and Ea-DfE gave high values of Trolox equivalent antioxidant capacity, whereas fraction Ea-DfE possessed 3,501.98, 2,967.85, and 8,673.35 $\mu \mathrm{M} \mathrm{TE} / \mathrm{mg}$ dry wt. that is a stronger antioxidant than fraction EaDfD which showed 3,552.52, 2,089.28, and 5,147.16 $\mu \mathrm{M} \mathrm{TE} / \mathrm{mg}$ dry wt. for ABTS, ORAC (Fig. 2), and FRAP assays, respectively (Table 2). Considering that Ea-DfD and Ea-DfE fractions are rich in phenolic acid derivatives that are well-known antioxidants, the ability to quench free radicals and consequently to prevent cancer can be explained by the presence of hydroxyl groups attached to aromatic rings (Golezar et al., 2017; Piazzon et al., 2012).

\section{LC-ESI-MS/MS profiling of two active subfractions (EaDf-D and EaDf-E) resulting from the total extract of the $E$. angustifolium aerial parts}

To explore the chemical profile of the two active fractions (EaDf-D and EaDf-E), LC-ESI-MS/MS was used in both ionization modes (negative and positive ion modes). The identification of the secondary metabolites was based on analysis of MS/MS data (i.e., molecular and fragments ions), retention times $\left(R_{\mathrm{t}}\right)$, and exploratory MS data of each compound in the mass bank, as well as the comparison with the published data in the literature. All the suggested secondary metabolites from the two analyzed fractions (EaDf-D and EaDf-E) and their fragmentations were summarized in Tables 3 and 4, respectively, and it was noticed that the peak number is the same as the compound number only in Table 3. The basic structures of the tentatively identified compounds from Ea-DfD and Ea-DfE are shown in Figure 3.

Basically, the LC-ESI-MS base peak chromatogram of the first active fraction (EaDf-D) in the negative and positive ion modes (Fig. 4) represented the tentative identification of nine phenolic compounds including six phenolic acid derivatives

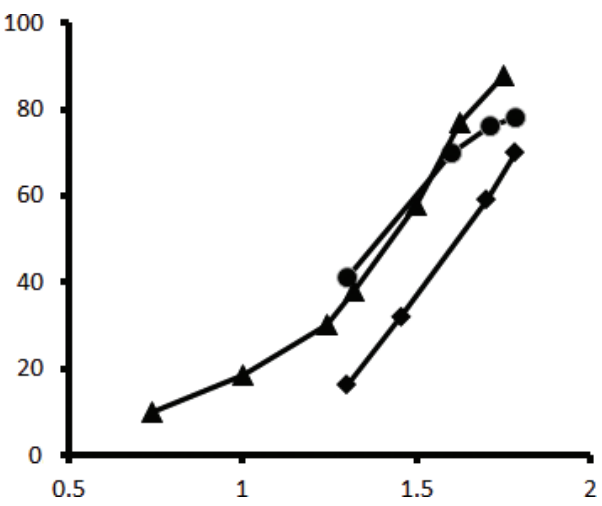

Figure 1. DPPH inhibitory action of Ea-DfD and Ea-DfE subfractions from the defatted extract of E. angustifolium and Trolox.

Table 1. Evaluation of the $\mathrm{IC}_{50}$ of the E. angustifolium aerial parts' extracts against the HEPG2 and HCT116 cancer cell lines.

\begin{tabular}{ccc}
\hline Fractions/doxorubicin & \multicolumn{2}{c}{$\mathbf{I C}_{\mathbf{5 0}}(\boldsymbol{\mu g} / \mathbf{m l})^{\mathbf{a}}$} \\
\cline { 2 - 3 } & HEPG2 & HCT116 \\
\hline Total extract (80\% EtOH) & $22 \pm 0.6$ & $15 \pm 1.1$ \\
EaDf & $20 \pm 0.6$ & $19.7 \pm 1.1$ \\
Ea-DfD & $10 \pm 0.2$ & $4 \pm 0.8$ \\
Ea-DfE & $4 \pm 0.5$ & $11 \pm 0.7$ \\
Doxorubicin (positive control) & $4.57 \pm 0.5$ & $3.73 \pm 0.6$ \\
\hline
\end{tabular}

${ }^{a}$ The activity was shown as $\mathrm{IC}_{50}$ value, which was the concentration of the tested extract $(\mu \mathrm{g} / \mathrm{ml})$ that decreased the number of viable cells by $50 \%$. Results are expressed as $\mathrm{IC}_{50} \pm \mathrm{SD}(n=3)$.

Table 2. Antioxidant activities of Ea-DfD and Ea-DfE subfractions from the defatted extract of the E. angustifolium aerial parts.

\begin{tabular}{|c|c|c|c|c|}
\hline \multirow[t]{3}{*}{$\begin{array}{l}\text { Fractions/ } \\
\text { Trolox }\end{array}$} & \multicolumn{4}{|c|}{$\begin{array}{c}\text { Antioxidant activity } \\
\text { Mean } \pm \text { SD }\end{array}$} \\
\hline & \multirow{2}{*}{$\frac{\mathrm{IC}_{50} \mu \mathrm{g} / \mathrm{ml}}{\mathrm{DPPH}}$} & \multicolumn{3}{|c|}{$\mu \mathrm{M}$ TE/ mg dry wt. } \\
\hline & & ABTS & FRAP & ORAC \\
\hline Ea-DfD & $42.61 \pm 2.17$ & $3,552.52 \pm 229.82$ & $2,089.28 \pm 128.21$ & $5,147.16 \pm 339.7$ \\
\hline Ea-DfE & $25.06 \pm 1.64$ & $3,501.98 \pm 212.95$ & $2,967.85 \pm 247.4$ & $8,673.35 \pm 1,650.66$ \\
\hline Trolox & $24.42 \pm 0.87$ & - & - & - \\
\hline
\end{tabular}


Table 3. Phytochemical compounds detected and suggested in the Ea-DfD subfraction resulting from the total extract of E. angustifolium aerial parts using LC-ESI-MS/MS in positive and negative ionization modes.

\begin{tabular}{|c|c|c|c|c|c|}
\hline No. & $\begin{array}{c}R_{\mathrm{t}} \\
\text { (minute) }\end{array}$ & $\begin{array}{c}(\mathbf{M}+\mathbf{H})^{+} \\
m / z\end{array}$ & $\begin{array}{c}(\mathrm{M}-\mathrm{H})^{-} \\
m / z\end{array}$ & Other fragments & Suggested compound \\
\hline 1 & $1.15^{b}$ & - & 197.1 & $153.1^{b}$ & Syringic acid (1) \\
\hline 2 & 2.45 & 181.1 & 179.1 & $163.0^{\mathrm{a}}$ & Caffeic acid (2) \\
\hline 3 & 5.88 & 438.3 & 436.3 & $292.2,147.0^{\mathrm{a}}$ & Dicoumaroyl-spermidine (3) \\
\hline 4 & 6.10 & 468.3 & 466.3 & $\begin{array}{l}436.3,292.2,147.0^{\mathrm{a}} \\
436.3,434.3,144^{\mathrm{b}}\end{array}$ & $\begin{array}{l}\text { Coumaroyl-feruloyl } \\
\text { spermidine }(4)\end{array}$ \\
\hline 5 & 6.22 & 498.4 & 496.4 & $\begin{array}{c}463.2,322.2,177.1^{\mathrm{a}} \\
461.2,353.2^{\mathrm{b}}\end{array}$ & Diferuloyl-spermidine (5) \\
\hline 6 & $6.36^{\mathrm{b}}$ & - & $1,013.5$ & $983.5,661.3,496.5^{b}$ & Echiumin A (6) \\
\hline 7 & 6.64 & 755.4 & 753.4 & $\begin{array}{c}741.3,455.2,383.1,163.0^{\mathrm{a}} \\
739.5,719.3,457.1,361.2 \\
360.2,359.2^{\mathrm{b}}\end{array}$ & Echiumin D (7) \\
\hline 8 & 6.86 & 985.5 & 983.5 & $\begin{array}{c}967.5,513.2,293.2,163.0^{\mathrm{a}} \\
953.5,733.4,193.1^{\mathrm{b}}\end{array}$ & Echiumin B (8) \\
\hline 9 & 7.99 & 209.1 & 207.1 & $163.0^{\mathrm{a}}$ & $\begin{array}{c}\text { Dimethylcaffeic acid } \\
\text { (3,4-dimethoxycinnamic } \\
\text { acid) (9) }\end{array}$ \\
\hline
\end{tabular}
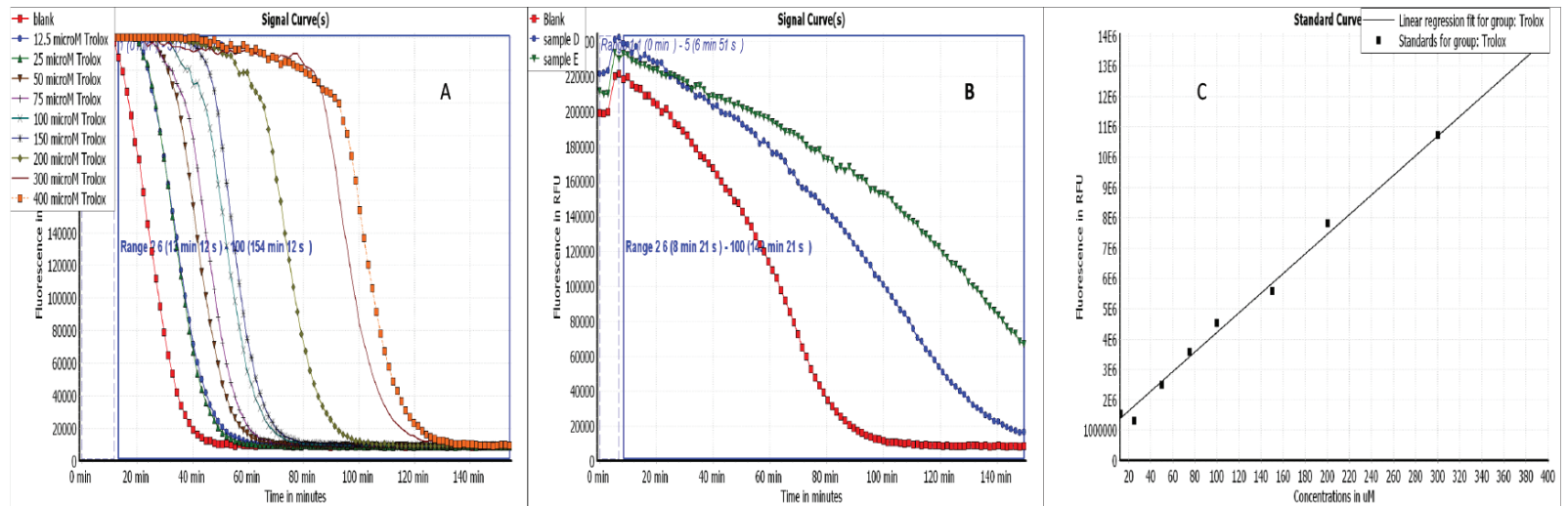

Figure 2. Antioxidant activities by ORAC assay. (A) Signal curves of different Trolox concentrations and blank indicating the decay of fluoresceine with different concentrations of Trolox. (B) Signal curves of Ea-DfD and Ea-DfE subfractions from the defatted extract of E. angustifolium and blank indicating the decay of fluoresceine upon applying the samples. (C) Blank corrected linear regression curve of Trolox.

and three lignans (Table 3). Compound 1 was detected only in the negative ion mode and showed $[\mathrm{M}-\mathrm{H}]^{-}$at $m / z 197.1$ and the fragment ion $153.1\left[\mathrm{M}-\mathrm{H}-\mathrm{CO}_{2}\right]^{-}$, with a neutral loss of $44 \mathrm{amu}$. This agreed with that of syringic acid (Purnamasari et al., 2021). Compound 2 revealed $[\mathrm{M}-\mathrm{H}]^{-}$at $\mathrm{m} / \mathrm{z}$ 179.1, 181.1 corresponding to $[\mathrm{M}+\mathrm{H}]^{+}$, and a fragment peak at 163 $\left[\mathrm{M}+\mathrm{H}-\mathrm{H}_{2} \mathrm{O}\right]^{+}$. Therefore, it was tentatively identified as caffeic acid (Purnamasari et al., 2021; Wei et al., 2010). Compound 9 presented molecular ions: $[\mathrm{M}+\mathrm{H}]^{+}$at $m / z$ 209.1, [M-H $]^{-}$at 207.1, and a fragment pattern at 163 . Thus, this compound might be associated with dimethylcaffeic acid (Mohamadi et al., 2015; Purnamasari et al., 2021). Compound 3 indicated $[\mathrm{M}-\mathrm{H}]^{-}$and $[\mathrm{M}+\mathrm{H}]^{+}$at $\mathrm{m} / \mathrm{z} 436.3$ and 438.3, respectively. Also, it showed fragmentations at $m / z 292.2[\mathrm{M}+\mathrm{H}-146]^{+}$and $147[\mathrm{M}+\mathrm{H}-291]^{+}$ consistent with the loss of coumaroyl and coumaroyl-spermidine moieties, respectively. These confirmed the identification of this phytochemical as N,N-dicoumaroyl spermidine (Ağalar et al., 2018; Collison et al., 2015). Similarly, the MS data of compounds $\mathbf{4}$ and $\mathbf{5}$ indicated that these two compounds could be identified as phenolic acid spermidine derivatives as well, whereas compound 4 gave molecular ions at $\mathrm{m} / \mathrm{z} 468.3[\mathrm{M}+\mathrm{H}]^{+}$and $466.2[\mathrm{M}-\mathrm{H}]^{-}$. Additionally, fragmentation patterns at $436.3[\mathrm{M}+\mathrm{H}-31]^{+}, 292.2$ $[\mathrm{M}+\mathrm{H}-176]^{+}$, and $147[\mathrm{M}+\mathrm{H}-321]^{+}$supported the presence of feruloyl and coumaroyl moieties attached to spermidine in the structure. By comparing our results with the literature (Ağalar et al., 2018; Cho et al., 2013; Wu et al., 2016), this compound 
<smiles>[R]OC(=O)/C=C/c1cc([R3])c([R1])c([R])c1</smiles>

(D)

(E)

Figure 3. Basic structures of the tentatively identified compounds from Ea-DfD and Ea-DfE fractions: (A) spermidine phenolic acids, (B) syringic acid, (C) other phenolic acid derivatives, (D) echiumin D, and (E) echiumins A and B.
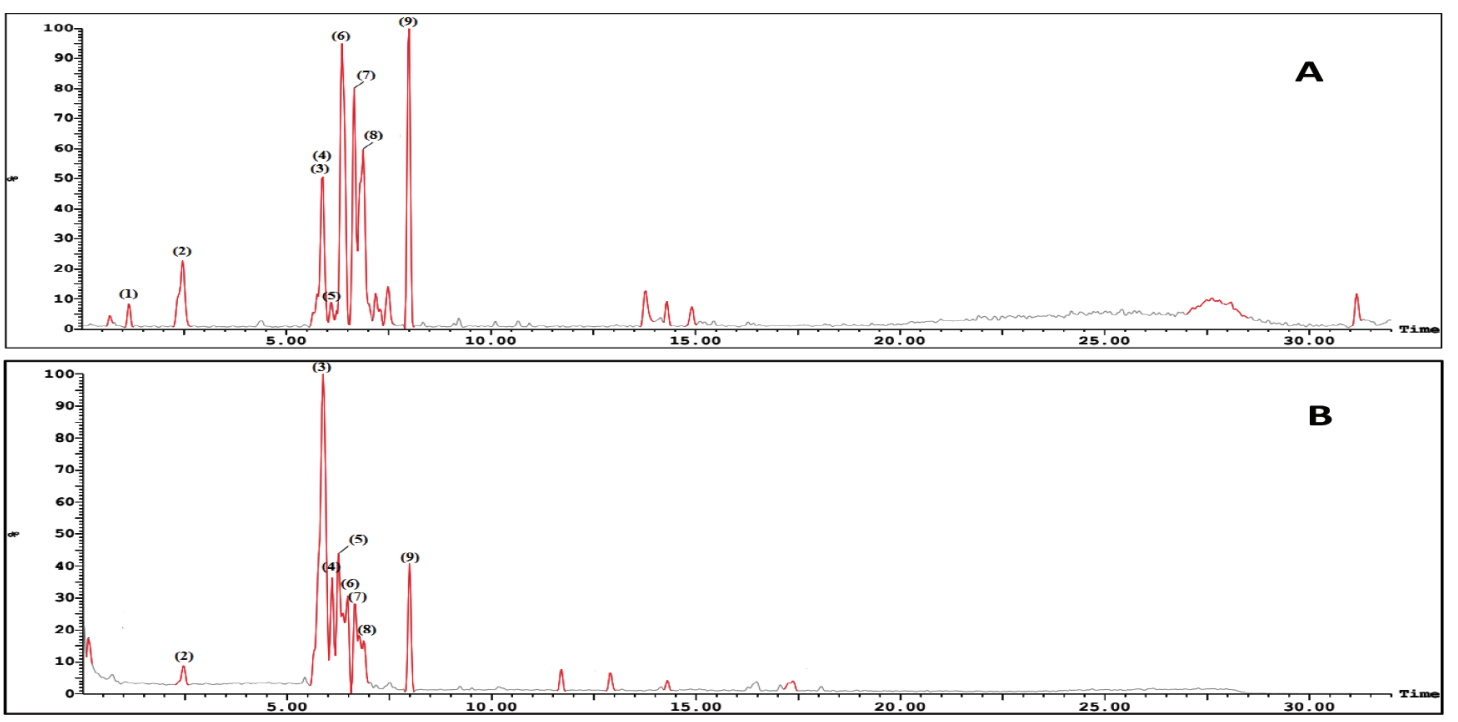

Figure 4. LC-ESI-MS base peak chromatogram of Ea-DfD fraction of the extract from the E. angustifolium aerial parts (A) in the negative mode and $(\mathrm{B})$ in the positive mode.

was tentatively identified as N-coumaroyl-N'-feruloyl spermidine, while compound 5 was suggested to be $\mathrm{N}, \mathrm{N}$-diferuloyl spermidine that showed $[\mathrm{M}+\mathrm{H}]^{+}$at $m / z 498.3,[\mathrm{M}-\mathrm{H}]^{-}$at 496.2, and fragments at $m / z 463.2,322.3[\mathrm{M}+\mathrm{H}-176]^{+}, 177.1[\mathrm{M}+\mathrm{H}-321]^{+}$, and 353.3 $[\mathrm{M}-\mathrm{H}-143]^{-}$and strengthened the attachment of two feruloyl moieties with spermidine constituting the compound structure.
Our findings were in agreement with the published data (Ağalar et al., 2018; Wu et al., 2016). The three latter compounds (6, 7, and 8) were matched and tended to be as echiumin A, echiumin $\mathrm{D}$, and echiumin $\mathrm{B}$, respectively, by comparing their MS findings with the previous data (El-Rokh et al., 2018b) which reported the isolation and identification of these sucrose diesters 
Table 4. Peak assignment of tentatively identified metabolites in the Ea-DfE subfraction obtained from the total extract of the E. angustifolium aerial parts using LC-ESI-MS/MS in positive and negative ionization modes.

\begin{tabular}{|c|c|c|c|c|c|}
\hline No. & $\underset{\text { (minute) }}{R_{\mathrm{t}}}$ & $\begin{array}{c}(\mathbf{M}+\mathbf{H})^{+} \\
m / z\end{array}$ & $\begin{array}{c}(\mathbf{M}-\mathbf{H})^{-} \\
m / z\end{array}$ & Other fragments & Suggested compound \\
\hline 1 & 6.74 & 438.1 & 436.2 & $292.0,146.8^{\mathrm{a}}$ & Dicoumaroyl-spermidine (3) \\
\hline 2 & $6.89^{\mathrm{b}}$ & - & 369.1 & - & Methylcaffeoyl glucuronide (10) \\
\hline 3 & 7.43 & 355.0 & 353.0 & $208.9,177.9^{\mathrm{a}}$ & $\begin{array}{l}\text { Chlorogenic acid (caffeoylquinic } \\
\text { acid) (11) }\end{array}$ \\
\hline \multirow[t]{2}{*}{4} & 7.66 & 385.0 & 383.0 & $208.9,162.8^{\text {a }}$ & Dimethylcaffeoyl glucuronide (12) \\
\hline & & & & $358.9^{\mathrm{b}}$ & \\
\hline
\end{tabular}

No. $=$ Identified peaks.

$\mathrm{a}=$ Positive ion mode.

$\mathrm{b}=$ Negative ion mode.
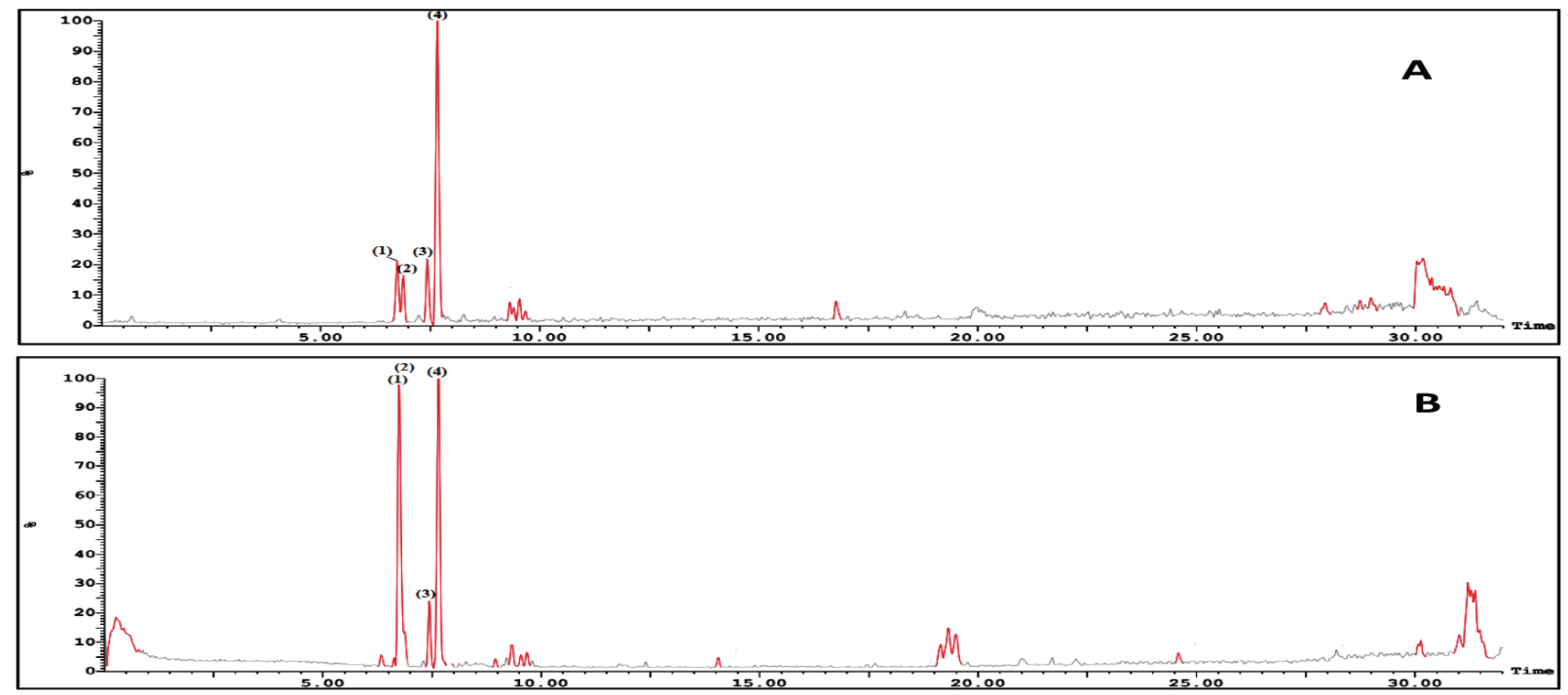

Figure 5. LC-ESI-MS base peak chromatogram of Ea-DfE fraction from the extract of the E. angustifolium aerial parts (A) in the negative mode and (B) in the positive mode.

of aryldihydronaphthalene-type lignans from our investigated plant (E. angustifolium) growing in Egypt. Our results showed that echiumin A (6) detected a molecular ion peak at $\mathrm{m} / \mathrm{z} 1013.5$ $[\mathrm{M}-\mathrm{H}]^{-}$, echiumin D (7) gave molecular ions at $\mathrm{m} / \mathrm{z} 755.4$ $[\mathrm{M}+\mathrm{H}]^{+}$and $753.4[\mathrm{M}-\mathrm{H}]^{-}$, and finally echiumin $\mathrm{B}(8)$ represented molecular ions at $m / z 1,007.4[\mathrm{M}+\mathrm{Na}]^{+}, 985.5[\mathrm{M}+\mathrm{H}]^{+}$, and 983.5 $[\mathrm{M}-\mathrm{H}]^{-}$. The existence of these lignan compounds in the EaDf-D fraction was reconfirmed by the TLC profile by the presence of some green fluorescence spots under long-wavelength UV (365 $\mathrm{nm})$, which is in agreement with El-Rokh et al., $2018 \mathrm{~b}$.

On the other hand, LC-ESI-MS of the second active fraction (EaDf-D) tentatively displayed assignment of four phenolic acid derivatives (Table 4) as shown in its base peak chromatogram in both ionization modes (Fig. 5). The first identified peak in this chromatogram showed the same mass spectrum as compound $\mathbf{3}$. Thus, it was tentatively identified as N,N-dicoumaroyl spermidine (Ağalar et al., 2018; Collison et al., 2015). The mass spectrum of peak (3) indicated molecular ions $[\mathrm{M}+\mathrm{H}]^{+}$at $\mathrm{m} / \mathrm{z} 355,[\mathrm{M}-\mathrm{H}]^{-}$at 353 , and $[\mathrm{M}+\mathrm{Na}]^{+}$at 377 and fragmentation ions at $\mathrm{m} / \mathrm{z} 208.9$ and 177.9 in the positive ion mode which revealed that this peak could be tentatively identified as chlorogenic acid, 11 (Chiang et al., 2004; Purnamasari et al., 2021). It was noticed that peak (2) represented just a molecular ion at $m / z 369.1[\mathrm{M}-\mathrm{H}]^{-}$, while peak (4) showed $[\mathrm{M}-\mathrm{H}]^{-}$and $[\mathrm{M}+\mathrm{H}]^{+}$at $\mathrm{m} / z 383$ and 385, respectively. Moreover, fragments at $\mathrm{m} / \mathrm{z} 163$ and $209[\mathrm{M}+\mathrm{H}-176]^{+}$corroborate a neutral loss of hexuronyl moiety (glucuronyl moiety), and by comparing these recent MS findings with the mass spectral data of compound 9 and the exploratory MS data of the suggested compound in the mass bank as well as by reviewing the literature (Piazzon et al., 2012), it can be suggested that peak (4) is thought to be tentatively identified as dimethylcaffeoyl glucuronide, 12, and consequently, peak (2) might be identified as methylcaffeoyl glucuronide, 10, with the absence of one methyl group compared to compound $\mathbf{1 2}$.

\section{CONCLUSION}

This work furnishes the first report on the presence of spermidine phenolic acid derivatives in Echium sp. in addition to some previously identified lignans that were tentatively identified by the LC/MS technique. All the suggested identified compounds (including phenolic acid derivatives and lignans) from fractions 
Ea-DfD and Ea-DfE of the E. angustifolium defatted part could be assumed to be responsible for the in vitro anticancer activity induced against liver and colon carcinoma cell lines. These fractions containing phenolic acid compounds were also found to possess strong antioxidant effect through different in vitro assays (DPPH, ABTS, FRAP, and ORAC). These varieties of tests represent different radical scavenging mechanisms by either hydrogen- or electron-donating ability that suggested these plant fractions to be active against many diseases related to oxidative stress, not only cancer. Consequently, further in vitro bioassays and in vivo tests of these plant active fractions are recommended to evaluate the plant, as well as its purified isolated compounds, to potentiate its claim as effective cytotoxic agents in liver and colon cancer treatments. Additionally, other biological screening will help in discovering other potential medicinal effects.

\section{AUTHORS' CONTRIBUTION}

All authors made the same contributions to the experiment design, analysis, and interpretation of data and writing the original draft and revising it.

\section{ACKNOWLEDGMENTS}

The authors gratefully acknowledge Professor Azza ElHadidy, Botany Department, Faculty of Science, Cairo University, Egypt, for authenticating their plant material. The authors also thank the National Cancer Institute (NCIE), Egypt, for carrying out the anticancer studies and appreciate Mr. Younan Ayad (Ain Shams University, Faculty of Pharmacy, Center of Drug Discovery, Research and Development) for providing LC/MS analysis.

\section{CONFLICT OF INTEREST}

The authors have no conflicts of interest to declare.

\section{ETHICAL APPROVAL}

No animals or human subjects were used in this study.

\section{REFERENCES}

Ağalar HG, Çiftçi GA, Göger F, Kırımer N. Activity guided fractionation of Arum italicum miller tubers and the LC/MS-MS profiles. Rec Nat Prod, 2018; 12(1):64-75.

Al-Madhagy SA, Mostafa NM, Youssef FS, Awad GE, Eldahshan OA, Singab AN. Metabolic profiling of a polyphenolic-rich fraction of Coccinia grandis leaves using LC-ESI-MS/MS and in vivo validation of its antimicrobial and wound healing activities. Food Funct, 2019; 10(10):6267-75.

Al-Rimawia F, Jaradatb N, Qneibic M, Hawashb M, Emwas N. Free radicals and enzymes inhibitory potentials of the traditional medicinal plant Echium angustifolium. Eur J Integr Med, 2020; 38:101196.

Arnao MB, Cano A, Acosta M. The hydrophilic and lipophilic contribution of total antioxidant activity. Food Chem, 2001; 73(2):239-44.

Bahmani M, Shirzad H, Shahinfard N, Sheivandi L, RafieianKopaei M. Cancer phytotherapy: recent views on the role of antioxidant and angiogenesis activities. Evid Based Complement Alternat Med, 2017; 22(2):299-309.

Benzie IF, Strain JJ. The ferric reducing ability of plasma (FRAP) as a measure of "antioxidant power": The FRAP assay. Anal Biochem, 1996; 239(1):70-6.

Bidak LM, Kamal SA, Halmy MWA, Heneidy SZ. Goods and services provided by native plants in desert ecosystems: examples from the northwestern coastal desert of Egypt. Glob Ecol Conserv, 2015; 3:433-47.
Boly R, Lamkami T, Lompo M, Dubois J, Guissou I. DPPH free radical scavenging activity of two extracts from Agelanthus dodoneifolius (Loranthaceae) leaves. Int J Toxicol Res, 2016; 8(1):29-34.

Chiang YM, Chuang DY, Wang SY, Kuo YH, Tsai PW, Shyur LF. Metabolite profiling and chemopreventive bioactivity of plant extracts from Bidens pilosa. J Ethnopharmacol, 2004; 95(2-3):409-19.

Cho K, Kim Y, Wi SJ, Seo JB, Kwon J, Chung JH, Park KY, Nam $\mathrm{MH}$. Metabolic survey of defense responses to a compatible hemibiotroph, Phytophthora parasitica var. nicotianae, in ethylene signaling-impaired tobacco. J Agric Food Chem, 2013; 61(35):8477-89.

Collison A, Yang L, Dykes L, Murray S, Awika JM. Influence of genetic background on anthocyanin and copigment composition and behavior during thermoalkaline processing of maize. J Agric Food Chem, 2015; 63(22):5528-38.

Dontha S. A review on antioxidant methods. Asian J Pharm Clin Res, 2016; 9(2):14-32.

El-Rokh AR, Negm A, El-Shamy M, El-Gindy M, AbdelMogib M. Insecticidal activity of Nitraria retusa and Echium angustifolium extracts and active metabolites against Aphis craccivora and Bemicia tabaci. J Modern Sci Eng, 2018a; 2(1):93-103.

El-Rokh AR, Negm A, El-Shamy M, El-Gindy M, Abdel-Mogib M. Sucrose diester of aryldihydronaphthalene-type lignans from Echium angustifolium Mill. and their antitumor activity. Phytochemistry, 2018b; 149:155-60.

Eruygur N, Yilmaz G, Kutsal O, Yücel G, Üstün O. Bioassayguided isolation of wound healing active compounds from Echium species growing in Turkey. J Ethnopharmacol, 2016; 185:370-6.

Eruygur N, Yilmaz G, Üstün O. Analgesic and antioxidant activity of some Echium species wild growing in Turkey. FABAD J Pharm Sci, 2012; 37(3):151-9.

Eruygur N. A simple isocratic high-perfomance liquid chromatography method for the simultaneous determination of shikonin derivatives in some Echium species growing wild in Turkey. Turk J Pharm Sci, 2018; 15(1):38-43.

Ghazanfar SA. Handbook of Arabian Medicinal Plants. CRC Press, Boca Raton, FL; Ann Arbor, MI; London, UK; Tokyo, Japan, pp 265, 1994.

Godlewska-Zyłkiewicz B, Swisłocka R, Kalinowska M, Golonko A, Swiderski G, Arciszewska Z, Nalewajko-Sieliwoniuk E, Naumowicz M, Lewandowski W. Biologically active compounds of plants: structure-related antioxidant, microbiological and cytotoxic activity of selected carboxylic acids. Materials, 2020; 13(19):4454.

Golezar E, Mahdiuni H, Nazari A. Different antioxidant activity measurements of the aerial parts of Ferulago angulata, traditional food additives in Iran. Indian J Pharm Sci, 2017; 79(6):900-6.

Kitessa SM, Nichols PD, Abeywardena M. Purple viper's bugloss (Echium plantagineum) seed oil in human health. Elsevier, Editors: Preedy VR, Watson RR, Patel VB. In: Nuts and seeds in health and disease prevention. Academic Press, Cambridge, MA, pp 951-8, 2011.

Liang Z, Cheng L, Zhong GY, Liu RH. Antioxidant and antiproliferative activities of twenty-four Vitis vinifera grapes. PLoS One, 2014; 9(8):e105146.

Mohamadi S, Zhao M, Amrani A, Marchioni E, Zama D, Benayache F, Benayache S. On-line screening and identification of antioxidant phenolic compounds of Saccocalyx satureioides Coss. et Dur. Ind Crops Prod, 2015; 76:910-9.

Özcan, T. Analysis of the total oil and fatty acid composition of seeds of some Boraginaceae taxa from Turkey. Plant Systemat Evol, 2008; 274(3):143-53.

Piazzon A, Vrhovsek U, Masuero D, Mattivi F, Mandoj F, Nardini M. Antioxidant activity of phenolic acids and their metabolites: synthesis and antioxidant properties of the sulfate derivatives of ferulic and caffeic acids and of the acyl glucuronide of ferulic acid. J Agric Food Chem, 2012; 60(50):12312-23.

Purnamasari V, Estiasih T, Sujuti H, Widjanarko SB. Identifcation of phenolic acids of Pandan anggur (Sararanga sinuosa Hemsley) fruits 
and their potential antiglycation through molecular docking study. J Appl Pharm Sci, 2021; 11(02):126-34.

Sadawe IA, Gbaj AA, Algheryane AO, Meiqal NH, Bensaber SM, Alshoushan AA, Gbaj HA, Maamar MS, Hermann A, Gbaj AM. Evaluation of aerial parts of Echium angustifolium on ciguatoxins toxicity using molecular modeling and albino mice models. MOJ Anat Physiol, 2020; 7(5):134-45.

Sarg T, El-Dahmy S, Abdel-Aziz E, Abdel-Ghani A, Roeder E. Pyrrolizidine alkaloids from Echium angustifolium. Fitoterapia, 1992; 63:466-8.

Skehan P, Storeng R, Scudiero D, Monks A, McMahon J, Vistica D, Warren JT, Bokesch H, Kenney S, Boyd MR. Newcoloremtric cytotoxicity assay for anti-cancer drug screening. J Natl Cancer Inst, 1990; 82(13):1107-12.

Teixeira J, Gaspar A, Garrido EM, Garrido J, Borges F. Hydroxycinnamic acid antioxidants: an electrochemical overview. Biomed Res Int, 2013; 2013:1-11. Article ID 251754. https://doi. org $/ 10.1155 / 2013 / 251754$

Wei Y, Gao Y, Zhang K, Ito Y. Isolation of caffeic acid from Eupatorium adenophorum spreng by high-speed countercurrent chromatography and synthesis of caffeic acid-intercalated layered double hydroxide. J Liq Chromatogr Relat Technol, 2010; 33(6):837-45.
Wu T, Lv H, Wang F, Wang Y. Characterization of polyphenols from Lycium ruthenicum fruit by UPLC-Q-TOF/MSE and their antioxidant activity in Caco-2 cells. J Agric Food Chem, 2016; 64(11):2280-8.

\section{How to cite this article:}

El-Tantawy HM, Hassan AR, Taha HE. Antioxidant potential and LC/MS metabolic profle of anticancer fractions from Echium angustifolium Mill. aerial parts. J Appl Pharm Sci, 2021; 11(12):200-208. 